\title{
'n Kritiese blik op missio Dei in die lig van Efesiërs
}

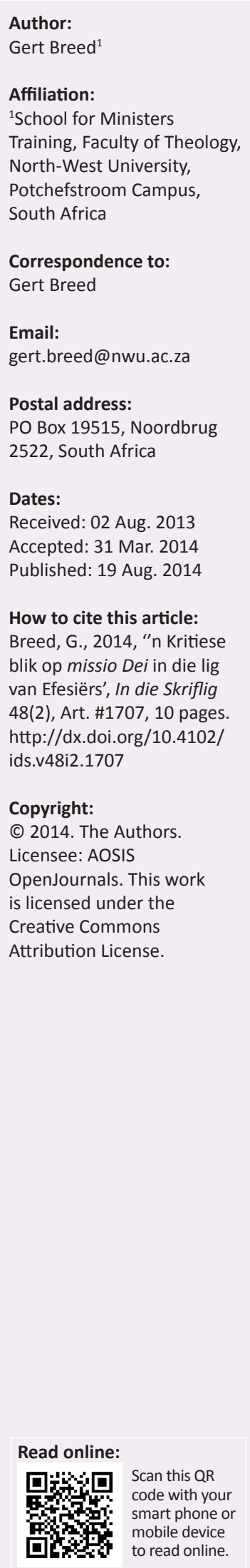

Missio Dei is 'n belangrike tegniese term in die gesprek oor die missionale taak van die kerk. Die term word egter nie konsekwent met dieselfde betekenis in die gesprek gebruik nie. Daar word selfs teenstrydige betekenisinhoude aan hierdie term geheg. Sommige gespreksgenote gebruik hierdie term sonder om duidelik te maak wat hulle spesifiek daaronder verstaan. Hierdie situasie lei tot misverstande en kan aanleiding gee tot 'n onbybelse benadering tot sending. Hierdie artikel ondersoek twee belangrike aspekte van die missio Dei-gesprek, naamlik die standpunt dat sending (missio) tot die wese van God behoort en dat Hy daarom 'n sendende God is, asook die standpunt dat sending (missio) uit die Drie-eenheid se onderlinge verhouding voortvloei. Verskillende benaderings in die missionale debat rondom die begrip missio Dei word krities ondersoek en op grond van Paulus se brief aan die Efesiërs geëvalueer. Vanuit die Efesiërbrief word 'n voorstel gemaak ten opsigte van die betekenis wat die begrip missio Dei behoort te dra asook hoe sending op die selfopenbaring van die Drie-eenheid volgens die Efesiërbrief gegrond kan word.

A critical view of missio Dei in the light of Ephesians. Missio Dei is an important technical term in the discussion of the missional task of the church. In this discussion, however, the term is not used in a consistent sense. Even contrary semantic contents are associated with it. Some participants in the discussion use the term without clarifying what they understand by it. This situation causes misunderstandings and may give rise to an unbiblical approach to mission. This article investigates two important aspects of the missio Dei discourse, namely the viewpoint that mission (missio) is inherent to the nature of God, which means he is a missional God, as well as the viewpoint that mission (missio) flows from the mutual relationship in the Trinity. Different approaches in the missional debate regarding the concept of mission Dei are critically investigated and evaluated on the grounds of Paul's letter to the Ephesians. Based on the Ephesian letter a suggestion is made with regard to what the meaning of the concept of missio Dei ought to be, as well as how mission can be based on the self-revelation of the Trinity according to the Ephesian letter.

\section{Inleiding}

Dat die kerk ' $n$ roeping het om as lig en sout van die wêreld te leef, is duidelik uit die Woord van God (Matt 5:13-16; 28:18-20; Joh 20:21; Hand 1:8; 1 Pet 2:9). Dat kerke dikwels hierdie roeping ignoreer of onderbeklemtoon, is uit die geskiedenis duidelik ${ }^{1}$ (Bolt \& Muller 1996; De Beer 2012:2-5; Smit 2010). Die onlangse belangstelling in en navorsing oor die missionale gerigtheid van kerkwees is dus welkom en kerke en navorsers moet deeglik hiervan kennis neem en hulleself daaroor verantwoord.

Wanneer verskillende skrywers se werk met mekaar vergelyk word, word dit egter duidelik dat daar min eenstemmigheid oor die betekenis van die verskillende begrippe in die missionale debat bestaan (Van Gelder \& Zscheile 2011:17). Skrywers gebruik hierdie begrippe sonder om te sê wat hulle daaronder verstaan, of om die begrippe aan die Woord te toets. Begrippe soos missio Dei en missionale kerk het soos 'n leë mandjie geword wat elke persoon met sy eie betekenisinhoud kan vul. Om hierdie rede wil sommige navorsers glad nie hierdie begrippe gebruik om God of die kerk se werk te beskryf nie (Keller 2012:258).

Hierdie artikel bestudeer enkele benaderings in die missionale debat rondom die begrip missio Dei en evalueer dit op grond van Paulus se brief aan die Efesiërs. Die doel van die artikel is om aan te dui dat daar met groot versigtigheid en helderheid aan die gesprek oor missio Dei deelgeneem moet word. Die noodsaak dat alle deelnemers duidelik sal uitspel wat hulle onder 'n bepaalde begrip verstaan, word aangetoon. Daar bestaan selfs die gevaar dat bepaalde maniere waarop 1.Vergelyk ook Buys (2011). 
mission Dei verstaan word, tot 'n verskraalde en eensydige Godsbegrip kan lei en dat dit skadelik vir die geldige bediening van die evangelie kan wees.

Die Efesiërbrief word ontgin om 'n korrektief te probeer bied op moontlike wanopvattings wat onder die begrip missio Dei verstaan word.

Vanweë die beperkte omvang van hierdie artikel kan elke saak wat in die missio Dei-gesprek ter sprake is, nie hier hanteer word nie. Die volgende twee belangrike beklemtonings in die resente literatuur word krities beskou om daardeur aan te toon dat ' $n$ deeglike besinning oor en ' $n$ definiëring van die begrippe wat in hierdie gesprek gebruik word, nodig is:

- Sending (missio) behoort tot die wese van God; God is daarom 'n sendende God.

- Sending (missio) vloei voort uit die onderlinge verhouding in die Drie-eenheid.

\section{Kritiese beskouing van beklemtonings in resente literatuur Sending (missio) behoort tot die wese van God}

Missio Dei beteken letterlik die sending van God. ${ }^{2}$ Sommige navorsers praat van God se selfsending, omdat die Vader die Seun gestuur het en die Vader en die Seun die Heilige Gees gestuur het en Jesus die kerk stuur (James 2013:377). Die begrip missio Dei is op sigself wyd en algemeen en word daarom met 'n wye verskeidenheid inhoude gevul (Günter 1998:56). Richebächer (2003:465) toon aan dat sommige navorsers die term missio Dei gebruik om die Christosentriese karakter van sending te beskryf (vgl. Hirsch 2006:83-110). Ander navorsers gebruik weer dieselfde term om die absolute aanspraak van die Christelike godsdiens te weerspreek deur daarmee 'n godheid te beskryf wat homself in verskeie godsdienste openbaar (vgl. ook Sundermeier 2003:560). Matthey (2002a:236-237) vra daarom vir die grootste versigtigheid wanneer hierdie term gebruik word, of anders dat die term glad nie gebruik behoort te word nie. Flett (2010:6) sê na aanleiding van verskeie skrywers se voorbehoude: 'Missio Dei is basic to a theological understanding of mission and dysfunctional to the point of being rejected ...' (vgl. ook Keller 2012:256).

'n Belangrike waarheid wat Bosch (2009:390) aan die uitdrukking missio Dei koppel, is dat God die begin en die einde van die sending is. Sending is nie in die eerste plek iets wat uit die inisiatief van die kerk ontstaan nie. Die kerk word deur God deel van sy koms na die wêreld gemaak (De Beer 2012:48). Sending het nie sy oorsprong in die kerk nie, maar in God (Wright 2013:xi). Hierdie stelling word in die Heidelbergse Kategismus, Sondag 21, antwoord 54 bevestig:

Dat die Seun van God uit die ganse menslike geslag vir Hom 'n gemeente wat tot die ewige lewe uitverkies is, deur sy Gees en Woord, in die eenheid van die ware geloof, van die begin van die wêreld tot die einde toe, vergader, beskerm en onderhou ...

2.Vir ' $n$ vollediger beskrywing van die historiese ontwikkeling van die begrip missio Dei, vergelyk Haaipiainen (2012:45), Hofmeyer (2001:108), Richebächer (2003) en Van Gelder (2007:13-27).
Alhoewel dit uit sowel die Ou Testament as die Nuwe Testament duidelik is dat God verskillende persone (Abraham, Josef, Moses, die profete, Johannes die Doper en Jesus, die apostels en die Heilige Gees) vir 'n wye verskeidenheid take stuur (Wright 2010:23, 24), kom die begrip missio Dei of die sending van God nie in die Bybel voor nie. Hierdie begrip het waarskynlik sy ontstaan reeds by Aurelius Augustinus in die 4de eeu n.C. (Engelsvike 2003:482; Müller 1985:57-59). Tydens die Ecumenical World Missions Conference in Willingen (1952) is sending vir die eerste keer in die Drie-eenheid van God geanker. Ná hierdie konferensie het George F. Viscedom die begrip missio Dei in sy boek met die gelyknamige titel gebruik (Vicedom 1958), waarna skrywers hierdie begrip algemeen begin gebruik het (Bosch 2009:390). Hierna het die verstaan van die oorsprong van sending 'n ingrypende verskuiwing ondergaan. Wat die subjek van sending betref, het dit van 'n antroposentries of ekklesiosentriese benadering na 'n teosentriese benadering verskuif. Wat die objek van sending betref, het dit van 'n ekklesiosentriese na 'n kosmosentriese benadering verskuif (Engelsviken 2003:481; Van Gelder \& Zscheile 2011:30). Hieruit het die verskillende benaderings soos dit vandag in die literatuur verwoord word, voortgevloei (Van Gelder \& Zscheile 2011:30, 31).

Die vraag waaroor dit hier gaan, is of stuur tot die wese van God behoort en of dit nie eerder beskou moet word as 'n daad van God wat vanuit sy liefde en genade voortkom (Joh 3:16) en in die uitvoering van sy ewige raadsplan (ekonomia; Ef 1:10) gestalte vind nie. Sommige skrywers oor missio Dei gaan van die standpunt uit dat 'God's being is in mission' (Hofmeyer 2001:109) en 'Die lewe van God is 'n proses van gestuurdheid' (Niemandt 2007:147). Bosch (2009:390) sê 'mission ... is an attribute of God. God is a missionary God'. Hiermee word uitdrukking gegee aan die feit dat sending nie as iets bykomstigs, toevalligs of nonessensiëels in God se verhouding tot die wêreld beskou moet word nie. Om God egter met een saak, naamlik sending te karakteriseer, maak sending dié saak wat God se wese beskryf. Dit kan tot ' $n$ verengde begrip lei van wie God is (Muse 2011). Dit kan ook daartoe lei dat die uiteindelike doel van God en sy skepping in die mens en die wêreld geplaas word (Scott 2010:342). Sending is 'n tydelike verskynsel wat duur vanaf die sondeval tot met die wederkoms van Christus, terwyl God en sy raadsplan van ewigheid tot ewigheid is. Kan God se wese daarom werklik met die term missio beskryf word?

Die antwoord op hierdie vraag word vervolgens in Efesiërs 1 gesoek. Efesiërs 1 kan as 'n beskrywing van die ekonomie (ewige raadsplan) van die drie-enige God beskou word (Breed 2013b; Floor 2011; Petrenko 2011:79-97; Pretorius 2006:256). In Efesiërs 1 word die werk van die drie-enige God op die volgende wyse beskryf: God die Vader het die gelowiges met alle geestelike seëninge in die hemel geseën en daarom het Hy hulle in Christus uitgekies en bestem om heilig en sonder gebrek voor hom in liefde te wees. Daarom het Hy hulle ook as sy kinders aangeneem (Ef 1:3, 4). Jesus het die verlossing van die uitverkorenes deur sy lewe en dood ('deur sy bloed'; Ef 1:6,7) bewerk. Die Vader het die gelowiges 
in die 'Geliefde' (Jesus) begenadig. Die Heilige Gees werk die wedergeboorte en die geloof in die uitverkorenes se harte en verseël hulle as eiendom van God (Ef 1:13, 14; Hoehner 2004:235-245). Die doel van hierdie verlossingsplan word in Efesiërs 1:10 soos volg beskryf:

... om die volheid van die tye te reël, met die doel om alle dinge wat in die hemele sowel as wat op die aarde is, onder een hoof in Christus te verenig. (1953-vertaling)

God se plan behels dat Hy die harmonie wat deur die sondeval verskeur is, wil herstel deur alles onder Christus weer bymekaar te bring (Breed 2013b). Hierdie vers dui duidelik die doel van God se sending van Jesus en die Heilige Gees aan en kan dus met die term missio Dei beskryf word. Hieruit is dit duidelik dat, volgens Paulus, die wese van God en sy dade van mekaar onderskei, maar nie geskei kan word nie $^{3}$ (vgl. Volf 2006b:108). Die herstel van die ganse skepping vind plaas deurdat elkeen van die drie Persone van die drie-enige God, in harmoniese samewerking met die ander twee persone, ' $n$ bepaalde bydrae lewer sodat die plan in die volheid van die tyd volgens God se besluit en welbehae in vervulling gaan (Floor 2011:468). God word nie sy dade nie en Hy is ook nie beperk tot sy ekonomie nie (Flett 2010:202). God openbaar wel iets van sy wese in sy ekonomie en daarom kan ons weet dat sending uit die wese van God voortvloei. God openbaar sy wese in sy dade: Paulus is 'n apostel wat die evangelie aan die heidene moet bring, omdat dit volgens God se wil is (Ef 1:1; 3:1-8); God reël alle dinge om volgens sy wil en voorneme op presies die regte tyd te gebeur $(E f 1: 9,10)$. God seën sy kinders uit die rykdom van sy genade (Ef 1:3, 7) en Hy begenadig sy kinders sodat hulle tot lof van sy heerlikheid kan wees (Ef 1:12). God doen alles in Christus deur die werk van die Gees (vgl. Hastings 2012:100-105). Uit hierdie dade van God kan iets van sy wese ontdek word, terwyl erkenning daaraan gegee moet word dat geen mens God ten volle kan ken nie. In die Efesiërbrief word dit telkens beklemtoon dat ons hier met 'n diep geheimenis te make het wat vir die mens onmoontlik is om uit sy eie ten volle te deurgrond (Ef 1:17-21; 3:1-5, 9, 17-20).

Wright (2008:531-535) se bydrae tot die gesprek oor missio Dei dui ' $n$ aanvaarbare rigting aan as antwoord op die vraag of missio God se wese kan beskryf. Hy vra of missio Dei as 'n hermeneutiese bril kan dien waardeur die hele Bybel gelees kan word. Sy antwoord is positief met die voorwaarde dat missio Dei as God se 'purposeful, sovereign intentionality' verstaan moet word. Die hele Bybel openbaar aan ons die volle raadsplan van God, 'the plan, purpose and mission of God for the whole creation, that it will be reconciled to God through Christ by the cross (Col 1:20)' (Wright 2008:531, 532). Goheen (2011:191) formuleer dieselfde oortuiging soos volg: 'God's mission is his long-term intention to bring about a renewed, restored heaven and earth.' Missio Dei moet dus nie tot die sending van die Seun, die Heilige Gees en die kerk beperk word nie. Wanneer

3.Dit is in teenstelling met die standpunt van Rahner (1970:22): :... the economic Trinity is the immanent Trinity, and the immanent Trinity is the economic Trinity'. Hierdie standpunt van Rahner het in sommige kringe van die missionale kerk en Hierdie standpunt van Rahner het in sommige kringe van die missionale kerk en
missio Dei-gesprek steeds ' $n$ bepalende invloed (vgl. Braaten 1990:419, 420; missio Dei-gesprek steeds 'n bepalende invloed (vg.
Hoffmeyer 2001:108; Van Gelder \& Zscheile 2011:33). die term missio Dei gebruik word, moet dit ook nie wees om God daardeur tot een modaliteit, naamlik sending, te beperk nie. Missio Dei moet eerder gebruik word as aanduiding van die ewige raadsplan van God wat in die hele Bybel beskryf word en wat die drie-enige God besig is om onkeerbaar in die volheid van die tyd uit te voer.

\section{Sending (missio) vloei voort uit die onderlinge verhouding van die Drie-eenheid}

Een van die winspunte van die missio Dei- en missionale kerkbeweging is dat die leer van die drie-enige God weer intensiewe aandag geniet en dat die betekenis van hierdie leer vir die praktyk van kerkwees en die sending opnuut ondersoek word. Soos met die begrip missio Dei is daar egter ook teenstellende inhoude wat aan hierdie leer gekoppel word. Daar word na twee kante toe gefouteer. In die eerste plek word die leer van die Drie-eenheid as 'n masker gebruik waaragter allerhande leerstellings weggesteek word en in die tweede plek word sending teologies in 'n beperkte leer van die Drie-eenheid begrond.

Daar word vervolgens by hierdie foutiewe opvattings stilgestaan en telkens word gepoog om die bybelse alternatief vanuit Efesiërs daarteenoor te stel.

\section{Die leer oor die Drie-eenheid as skuilplek vir dwaalleer}

Roxburgh en Boren (2009:133) verwoord 'n toepassing van die missionale teologie wat algemeen in sommige kringe $^{4}$ gevind word. Hulle sê dat die kerk die nie-hierargiese onderlinge gemeenskap of interaksie binne die Drie-eenheid (social Trinity) moet navolg en daarom 'n dinamiese, toeganklike en oop verhouding met die wêreld behoort te hê (vgl. ook Keller 2012:263; Meeks 2006:13; Purves 2011:16, 17). Van hierdie tipe toepassing sê Flett $(2010: 9,10,49)$ dat dit in gebreke bly om die unieke werk van die Vader, die Seun en die Heilige Gees te beskryf en dat dit slegs 'n metafoor word van 'n abstrakte dinamiek wat vaagweg aan die lewe van die Drie-eenheid verwant is. Matthey (2002b:582) vra wie die mens is om die innerlike lewe van God te ken; wanneer ons buite die openbaring van die Woord probeer delf 'we could easily fall into the temptations of transferring to God our vision of the ideal community or society' (vgl. ook Volf 2006a:4).

Flett (2010) spel die probleem wat hieruit ontwikkel soos volg uit:

One can doubt neither the biblical provenance of the term 'sending' nor the potential link this establishes between the missionary act and the doctrine of trinity. Problems emerge in

4.Vergelyk Janse van Rensburg (2011:61-123) vir 'n detailbespreking van die verskillende rigtings waarin die 'emergent church'-beweging asook sekere SuidAfrikaanse kerkleiers hulle toepassings maak. Driscoll (2008) onderskei die volgende vier bane waarin die 'emergent church' ontwikkel het: 'Emerging Evangelicals', 'House Church Evangelicals', 'Emerging Reformers' en 'Emergent Liberals'. Hy bespreek elkeen van die bane in detail, maar maak egter ook ' $n$ tweedeling: in die eerste drie bane is persone en kerke wat die gesag van die Skrif erken en daarvolgens wil handel, terwyl diegene in die vierde baan hulle nie aan die gesag van die Skrif onderwerp nie; hulle wil geheel en al vrydenkend na nuwe wyses van kerkwees soek. Die hoofrolspelers in die vierde baan is Brian McLaren, Doug Pagitt en Rob Bell. 
the way 'sending' provided merely a trinitarian facade, behind which a range of alternate doctrines informed the material content of missio. (p. 48)

Braaten (1990:421) dui een van hierdie alternatiewe leerstellings aan wanneer hy die sogenaamde paradigmaskuif beskryf wat by die postmoderne mens voorkom. Hierdie siening berus op 'n pluralistiese, teosentriese model waarin verskeie godsdienstige sienings geakkommodeer word. God en nie Jesus Christus nie, beklee die middelpunt van die heelal. Alan Hirsch (2006:83-100) bespreek wat hy noem die 'epicentre' van die kerk se boodskap. Hy sluit aan by Israel se belydenis in Deuteronomium 6 waar hulle Jahwe as die enigste Here bely. Hy toon aan dat hierdie monoteïstiese belydenis in die $\mathrm{Ou}$ Testament oorgegaan het in die belydenis 'Jesus is Here'. Jesus vorm daarom die middelpunt van die kerk se boodskap en die kern van die missionale werk van die kerk. Jesus is Here en sal alle dinge aan Homself onderwerp totdat Hy uiteindelik alle dinge, ook Homself, aan die Vader onderwerp. Die wat hierdie sentrale plek van Chrsitus ontken of misken, kom uiteindelik by die oortuiging uit dat die kerk sonde moet herdefinieer; sonde is dan nie meer 'n oortreding teen God nie, maar moet in horisontale terme beskryf word as die verbreking van God se shalom. ${ }^{5}$ Die doel van sending is dan nie meer die verkondiging van die versoening wat Christus bewerk het nie, maar om mense deel van die nuwe gemeenskap te maak wat met God saamwerk om sosiale strukture te vernuwe en die wêreld te genees ${ }^{6}$ (vgl. ook Sundermeier 2003:561). Sweet (2010:15) beweeg in dieselfde rigting wanneer hy sê dat daar vanweë die ingrypende verandering in mense se lewens- en werklikheidsbeskouing 'n perfekte storm heers en dat die kerk hierby moet aanpas of sterf. Smit (2010:3) sluit by hierdie denkrigting aan en sê dat die postmoderne mens se behoeftes in ag geneem moet word. Daarom vind 'die uitnodiging tot dissipelskap deur gevoel, musiek en energie plaas' en die klem moet nie op 'n stel waarhede gelê word nie. Die mens en die kultuur word hierdeur die bepalende faktor in God se verhouding met die mens. Keller (2012:252) toon aan dat Konrad Rahner die Wêreldraad van Kerke gelei het na 'n standpunt dat dit die Vader se wil is dat daar reg en geregtigheid sal geskied, dat daar vrede sal wees en dat Hy sy Gees gestuur het om dit op 'n verskeidenheid maniere te bewerk. Christus word doelbewus uit hierdie siening van sending weggelaat, sodat die verskillende godsdienste kan saamwerk. Keller (2012:257, 256-258) asook Van Gelder en Zscheile (2011:67-98) dui aan dat die alternatiewe inkleding van die leer oor die Drie-eenheid in ' $n$ wye verskeidenheid rigtings ontwikkel - dié van Roxburgh en Boren en dié wat Braaten beskryf en waarby Konrad Rahner se siening aansluit, is maar drie rigtings (vgl. ook Flett 2010:41, 42; Engelsviken 2003:493, 494).

Niemandt (2008:618) sê in aansluiting by verskeie skrywers wat deel van die meer liberale vertakking van die emerging church-beweging uitmaak (byvoorbeeld Sweet, Mclaren,

5.Die begrip shalom word ook in die literatuur met'n verskeidenheid betekenisinhoude gevul.

6.Wright (2006) neem hierdie standpunt in (vgl. ook Van Gelder \& Zscheile 2011:84).
Frost), dat die missionêre leier by God se hede en toekoms, deur verbeelding, moet aansluit. In hierdie aansluiting by die missio Dei is verbeelding belangriker as kennis. Hy bly egter vaag oor wat die verband van hierdie stelling met die kennis van die drie-enige God en sy Woord is. Niemandt (2008) maak die volgende stelling oor die kultuur wat in missionale gemeentes moet heers:

Dit is 'n kultuur wat 'n omgewing van berekende onsekerheid en vaagheid skep en wegstuur van absolute sekerhede en gemaklike antwoorde op alle uitdagings. Chaos is eintlik 'n voorwaarde vir kreatiewe herskepping. (bl. 619)

Weereens word geen verband gelê met die sekerheid van God se selfopenbaring in sy Woord nie en ook nie wat die grense van verbeelding is nie. Niemandt (2008:619) sê verder: 'Diversiteit en anders-denkendes word gekoester as spesiale gawes aan die kerk en [is] een van die sleutels tot innovasie.'

Wanneer 'n mens die feit in ag neem dat Niemandt (2008:606, 609), Roxburgh (sien hierbo) goedkeurend aanhaal en as 'n venoot beskou, ontstaan die vraag of hy met laasgenoemde aanhaling die akkommodering van nie-Christelike gedagtes insluit. Dit lyk inderdaad asof Niemandt (2008:619) in sy artikel "n omgewing van berekende onsekerheid en vaagheid skep' waarin elkeen sy eie interpretasie kan inlees.

Wanneer die begrip missio Dei en die leer oor die Drie-eenheid op hierdie wyse gebruik word, skep dit 'n teelaarde vir misverstand en dwaalleer in die kerk van die Here. Dit is daarom noodsaaklik om hierdie begrippe met 'n duidelike bybelse inhoud te vul of alternatiewe terme te vind.

Volf (2006b:105-108) vergelyk die twee uiterstes in hierdie gesprek, naamlik om aan die een kant te glo dat die drie-enige God ten volle in die mens se sosiale omgang nagevolg kan word en aan die ander kant, om te glo dat God glad nie nagevolg kan word nie. Hy sê dat die vraag eerder moet wees waarin die gelowiges God wel in hulle verhoudings op aarde kan en moet navolg. Hierdie antwoord word gevind in God se openbaring in sy Woord en die praktiese toepassing van die Woord op die lewenswerklikhede van die tyd waarin die kerk leef.

Uit die brief aan die Efesiërs is dit duidelik dat kennis van die drie-enige God en die besonderhede van sy verlossingsplan 'n baie belangrike rol in die uitvoering van hierdie plan speel.

Op verskeie plekke in die Efesiërbrief word die belangrikheid van kennis aangaande die drie-enige God beklemtoon. In Efesiërs 1:7-9 word gesê dat die gelowiges God se genade ontvang het 'deurdat Hy aan ons die verborgenheid van sy wil bekend gemaak het na sy welbehae wat Hy in Homself voorgeneem het' (1953-vertaling).

Paulus bid twee keer in Efesiërs vir die gelowiges se groeiende begrip van dit wat hulle ontvang het (Ef 1:15-23; 3:14-21). In Efesiërs 4:15 sê Paulus dat die groei na volwassenheid in die gemeente plaasvind 'terwyl ons in 
liefde die waarheid betrag' (1953-vertaling). In Efesiërs 4:20 word die belangrikheid van die kennis van die drie-enige God egter die helderste beskryf.

Efesiërs 4:20 word vervolgens binne die verband van Efesiërs 4-6 ondersoek.

Uit Efesiërs 4-6 is dit duidelik dat die ontginning van die leer oor die Drie-eenheid van kardinale belang is vir die pastorale begeleiding van nuwe gelowiges tot die oorwinning oor die sonde in hulle lewe (vgl. Breed 2013c:234; 2013b; Jordaan 1990).

In Efesiërs 4:1 word die gelowiges opgeroep (vermaan) om waardig aan die roeping waarmee hulle geroep is, te wandel. Navorsers toon aan dat hierdie vers die tweede deel van die brief inlei (Jordaan 1990). Die vers begin met die partikel oun wat daarop dui dat dit wat volg 'n gevolg van die voorafgaande (Ef 1-3) is (Hoehner 2002:500). In hierdie tweede deel word die praktiese uitwerking van wat volgens God se raadsplan met hulle gebeur het, vir die gelowiges uitgespel. Die voorskrifte vir hierdie nuwe gelowiges hoe hulle hul roeping moet uitleef, vloei voort uit hulle begrip van en verhouding met die drie-enige God. Die verhouding word bepaal deur hulle kennis en begrip van wie God is.

Efesiërs 4:1-6 verduidelik hoe die eenheid in die gemeente in die Vader, Seun en Heilge Gees gegrond is. Efesiërs 4:7-16 verduidelik hoe die gawes van die Gees, wat Christus uitdeel tot opbou van die liggaam, gebruik word wanneer gelowiges aktief raak om elkeen se besondere gawes te gebruik (vgl. Ef 2:10).

Efesiërs 4:17-6:20 is 'n begeleiding van jong gelowiges om die nuwe lewe en die seëninge van hierdie nuwe lewe in die praktyk van elke dag te verwerklik. Hulle kan dit net doen deur in 'n noue verhouding met die drie-enige God te leef (Petrenko 2011:161). Hierdie waarheid word duidelik in Efesiërs 4:20: In Efesiërs 4:17-19 beskryf Paulus die lewenswyse waarmee die gelowiges moet breek. Hy lê besondere klem op die gebrek aan kennis en begrip asook die leegheid van die lewenswyse sonder God (Petrenko 2011:163, 164). Efesiërs 4:20 verteenwoordig 'n oorgang na die beskrywing van hoe gelowiges wel moet lewe. Die woord manthano dra verskeie betekenisse in die Nuwe Testament (vgl. Hoehner 2002:591, 592), maar slegs hier word dit gebruik om aan te dui dat iemand 'n persoon leer (ken) ('learning a person' - Hoehner 2002:594; Fowl 2012:150). Die vers kan dus soos volg vertaal word: 'Maar julle het Christus nie so leer ken nie' ('The implication is that factual learning is insufficient, the goal is to know Christ personally'; Hoehner 2002:594). Dit gaan dus nie oor blote kennis aangaande Jesus nie, hulle het Jesus as persoon leer ken, maar nog meer, hulle het ' $n$ bepaalde lewenswyse en lewensuitkyk leer ken.

Hierdie waarheid word ook in Filippense 2 beskryf waar die gelowiges die opdrag ontvang om eensgesind te wees (Fil 2:2). Hierdie opdrag berus op die indikatief wat in
Filippense 2:1 beskryf word, naamlik die troos, liefde en innige gemeenskap wat hulle van die drie-enige God ontvang het (Purves 2011:20). Hulle ontvang die opdrag om dieselfde gesindheid as Christus te hê, naamlik dat Hy bereid was om alles te doen wat nodig is om dít waarvoor sy Vader Hom gestuur het, uit te voer (Fil 2:5-8; Purves 2011:20, 21) in die vertroue dat sy Vader Hom sal verhoog en sal verheerlik soos Hy belowe het (Fil 2:9-11; Bauckham 2008:54, 55). Jesus se gesindheid kom na vore in sy gewillige ontlediging en vernedering van Homself in gehoorsaamheid aan sy Vader (Purves 2011:21). Die gelowiges moet nie slegs Jesus se voorbeeld volg nie (Witherington 2011:14), maar hulle ook met Hom identifiseer.

In die lig van hierdie gedeelte (Fil 2) kan gesê word dat Paulus waarskynlik bedoel het dat die lesers van die Efesiërbrief Jesus ook moet leer ken in hierdie gesindheid en dat die opdragte wat in die res van die brief gegee word vanuit hierdie kennis voortvloei (vgl. Ef 4:21; 5:1, 2). Die kennis van Christus verander die wyse waarop iemand dink en na die wêreld en ander mense kyk (jou hartsoortuiging). Uit hierdie nuwe oortuiging vloei 'n nuwe optrede voort (vgl. Ef 4:22-24). Petrenko (2011:172) noem dit 'a new structure of perception and knowledge'.

In Efesiërs 4:24 word die verandering wat in die gelowige plaasgevind het met skeppingswoorde beskryf: 'lewe as nuwe mense wat as die beeld van God geskep is: lewe volkome volgens die wil van God en wees heilig' (1953-vertaling). Die gelowiges het Christus leer ken toe hulle onderrig is in die waarheid wat in Jesus is (Ef 4:21). Hierdie waarheid is Jesus, die Woord waardeur alle dinge geskep is (Joh 1:1) en waardeur die herskepping ook plaasgevind het. Om as nuwe mense as kinders van God te leef wat Hom navolg (Ef 5:1) en in die liefde van Christus te lewe (Ef 5:2), moet hulle voortdurend met die Heilige Gees vervul word (Ef 5:18). Wanneer hulle nie so leef nie, bedroef hulle die Heilige Gees (Ef 4:30). Hulle is in Christus herskep om die goeie dade wat God vir hulle voorberei, in hulle lewenswandel te doen (Ef 2:10). Om hierdie goeie dade of dienswerk te kan doen, skenk Christus aan elke gelowige genadegawes en aan die kerk besondere gawes om die gelowiges vir hulle dienswerk toe te rus (Ef 4:1-16). Die kerk is die plek waar toerusting en opbou plaasvind sodat die gelowiges hulle dienswerk kan verrig om daardeur die liggaam van Christus tot sy volle grootte te laat groei (Ef 4:13; Breed 2012:3).

Die nuwe lewe waarvoor hulle toegerus word deur hulle groeiende kennis van die drie-enige God word in Efesiërs 5:1-2 soos volg beskryf:

Wees dan navolgers van God soos geliefde kinders en wandel in liefde, soos Christus ons ook liefgehad het en Hom vir ons oorgegee het as 'n gawe en offer aan God tot 'n lieflike geur.

Sending word dus in navolging van die drie-enige God gedoen, maar dit is nie 'n vae na-aap van elkeen se eie idee van 'n veronderstelde 'social Trinity' of "n kultuur wat 'n 7.Vergelyk ook Vetö (1996) se navorsing oor Jonathan Edwards se siening van geestelike en/of geloofskennis. 
omgewing van berekende onsekerheid en vaagheid (skep)' nie (Niemandt 2008:619). Dit is ook nie 'n openheid wat verskillende sienings onkrities akkommodeer nie. Sending word gegrond op die wete dat kennis van God moontlik is, dat die waarheid teenoor die leuen en dwaling geken kan word en dat nuwe gelowiges begelei moet word tot 'n groeiende, intieme kennis van God waaruit die 'breek met die ou mens' en die 'opstanding van die nuwe mens' kan plaasvind (vgl. Breed 2013c:237-240). Die unieke, sentrale plek en werk van Jesus Christus binne die raadsplan van God kan nie ontken word sonder om die hart uit die sendingwerk te verwyder nie (De Beer 2012:56). In navolging van God wat heilig is, moet die kind van God ook heilig lewe, gewas in die bloed van Christus en nuut gemaak deur die Heilige Gees, en moet hulle in hulle toewyding aan God groei.

\section{Sending; teologies in ' $n$ beperkte leer oor die Drie-eenheid begrond}

Sommige skrywers (Hastings 2012:77) sê dat die sending van die kerk in die drie-enige God se wese begrond is, maar al waarin hulle die sending begrond is die feit dat die Vader die Seun gestuur en die Vader en die Seun die Gees gestuur het en dat die Seun die kerk gestuur het. Bosch $(1985: 533,534)$ waarsku: 'it is unwarrented to single out the verb "send" as the key verb in scripture'. Verder sê hy om een woord uit te sonder beteken dat ' $n$ mens sending die essensie, nie net van sending nie, maar van die totale teologie van die Skrif maak. ${ }^{8}$ Flett (2010:48, n. 38) sluit by hierdie waarneming van Bosch aan en sê: 'This astute observation illustrates key flaws within missio Dei: "sending" lacks substance and yet comes to have a determinative effect on the doctrine of God.'

Hieruit is dit duidelik dat dit noodsaaklik is vir kerke en navorsers wat aan die gesprek oor missio Dei en die missionale kerk deelneem, om hulle standpunt oor die leer van die Drie-eenheid en die begronding van die sending in hierdie leer duidelik uit te spel en daarna te streef om die diepte van hierdie leer te ontgin as ' $n$ basis vir die sending (James 2013:377).

Alhoewel dit buite die skopus van hierdie artikel val om 'n diepgaande studie te maak van die leer van die Drie-eenheid as grondslag vir die sending van die kerk, word nou kortliks uit Efesiërs aangetoon hoe die begronding van die sending in die leer oor die drie-enige God in groter diepte kan plaasvind.

\section{Begronding van die sending in die leer oor die drie-enige God \\ Die Vader, Seun en Heilige Gees dra elkeen by tot die uitvoering van die ewige raadsplan}

Die brief aan die Efesiërs is aan gelowiges uit die Jode asook gelowiges uit die heidendom gerig (Ef 2). In Efesiërs 1:10 verduidelik Paulus die oorsprong van hulle geloof en van die kerk, naamlik as God se raadsplan. In Efesiërs 1 word die taak van elkeen van die Persone van die Drie-eenheid opgesom asook die werksverhouding tussen die drie Persone

8.Vergelyk Wright (2010:201-221) vir' $n$ begronding van sending in die Ou en Nuwe Testament.
(Floor 2011:470; vgl. 'Sending (missio) behoort tot die wese van God' hierbo). Paulus is 'n apostel van Jesus Christus deur die wil van die Vader (Ef 1:1). God die Vader van die Here Jesus Christus het die gelowiges in Christus geseën met al die seëninge van die Gees (Ef 1:3,4) - hulle is daarvoor bestem om deur Christus die Vader se kinders te wees (Ef 1:5). Jesus is die Geliefde van die Vader (Ef 1:6; 1953-vertaling). God bring sy besluit deur Christus tot uitvoering en sy doel is om alles (dit sluit die ganse skepping in) weer en/of opnuut (Floor 2011:473, 474; Petrenko 2011:95, 96) onder Christus in harmonie saam te bring (Ef 1:10). Deur Christus word die gelowiges deel van God se volk volgens sy raadsbesluit (Ef 1:12; 1983-vertaling). Die Heilige Gees beseël die gelowiges in Christus as die eiendom van God (Ef 1:13; 1983-vertaling). Die Heilige Gees is die waarborg dat die gelowiges alles sal ontvang wat God belowe het wanneer almal wat aan Hom behoort volkome verlos word (Ef 1:14; 1983-vertaling).

Hieruit is dit duidelik dat die Vader, die Seun en die Heilige Gees saam as één God die raadsplan tot herstel van die skepping uitvoer op die bestemde tyd, tot verlossing van die mense wat Hy uitverkies het, tot lof van die drie-enige God (Floor 2011:477, 478). Hoewel dit duidelik is dat daar 'n harmonieuse verhouding en samewerking tussen die drie Persone van die één God is, val die klem eerder op wat elkeen doen en nie op hulle onderlinge verhouding nie.

Hierdie leer word in verskeie ander Skrifgedeeltes (Hand 18:9-11; 1 Pet 2:9) bevestig, waarvan slegs 'n enkele voorbeeld aangetoon word. In Johannes 6 word gesê dat die Vader mense aan Jesus gee, hulle na Jesus trek en hulle leer sodat hulle glo en na Jesus kom. Niemand kan na Jesus kom as hulle nie deur die Vader gestuur is nie (Joh 6:44, 45, 65). Almal wat die Vader aan Jesus gee, sal na Hom toe kom en Hy sal niemand wat na Hom toe kom, verwerp nie (Joh 6:37). Jesus sal hierdie gelowiges bewaar sodat niemand wat die Vader Hom gegee het, verlore sal gaan nie. Hy sal hulle in die laaste dag uit die dood opwek (Joh 6:38; vgl. ook 10:28). Die Gees moet hierdie mense lewend maak, want uit hulleself kan hulle nie glo nie (Joh 6:63).

Hieruit kan die volgende toepassing op die sendingtaak gemaak word:

- God is besig om sy raadsplan onkeerbaar ten uitvoer te bring.

- Die Vader, Seun en Heilige Gees, as die één en enigste God, verseker self die verloop en die sukses van hierdie plan.

- God se plan is 'n ewige plan waarvan 'n deel in die tyd plaasvind en 'n ander deel in die ewigheid.

- God se plan het op sy ganse skepping betrekking en loop daarop uit dat alles onder die een Hoof, Christus, in volmaakte harmonie saamgebring word.

- Die Vader doen alles in Jesus Christus deur die kragtige werking van die Gees.

- Sending word in die sekerheid gedoen dat die uitkoms nie van mensewerk afhanklik is nie, maar ook in die 
nederigheid van iemand wat weet dat hy 'n medewerker van die almagtige God is.

- Enige uitreik wat gedoen word sonder dat die werk van elkeen van die drie Persone in ag geneem word, gaan in téén die raadsplan van God.

- Sending moet biddend gedoen word, soekend daarna om die tekens van die tyd van God se plan te begryp en sy wil vir' $n$ bepaalde tyd te soek.

Uit Efesiërs is dit ook duidelik dat die verlossingsdade van die drie-enige God en die praktiese toepassing daarvan in die gelowige se lewe van besondere belang vir die begronding van die kerk se sendingtaak in die Drie-eenheid is. Die belang hiervan word vervolgens uit Efesiërs aangetoon.

\section{Die verlossingsdade van die drie-enige God en die praktiese toepassing daarvan in die gelowige se lewe}

In Efesiërs 2 verduidelik Paulus aan die jong gelowiges hoe hulle van hulle vorige lewe gered is en hoe hulle deel geword het van God se volk. In Efesiërs 3 beskryf Paulus sy rol as apostel om die kerk tot stand te bring as 'n openbaring van die geheimenis van God se raadsplan. Efesiërs 1-3 is in die vorm van 'n Berakah-gebed geskryf en begin en eindig met lof aan God. Twee keer in hierdie gebed bid Paulus dat die gelowiges sal begryp wat hulle van God ontvang het. Efesiërs 4-6 kan gesien word as die pastorale begeleiding van die jong gelowiges om hulle nuwe identiteit in Christus uit te leef (Jordaan 1990; Breed 2013b). Deur die hele brief word die Vader, Seun en Heilige Gees as die begin en einde van die verlossing en oorwinningslewe verkondig.

Die totale verlossingsplan is van die werk van elkeen van die drie Persone van die Drie-eenheid afhanklik. In die kern van hierdie verlossingsplan staan Jesus Christus as persoon en sy volmaakte gehoorsaamheid aan die Vader. Deur sy lewe, sterwe en opstanding het Hy die wet in die mens se plek volbring en die mens met God versoen. Die Vader het Hom uit die dood opgewek en alle dinge aan Hom onderwerp (Ef 1:20-22). God se heerskappy strek dus oor die ganse aarde. Elkeen wat deur die geloof 'n kind van God word, kry op 'n besondere wyse deel aan die koninkryk wanneer die Gees van God dit wat Christus gedoen het, in hulle lewe indra. Daardie mense word verlos van die mag van die bose en van die verslawing van hulle begeertes (Ef 2:1-5) en kan in die lig onder Christus se heerskappy heilig en vervuld met die Gees lewe (Ef 5:1-18). 'n Persoon wat in die sonde volhard en nie deur die Gees meer en meer teen die sonde stry en daarmee breek nie, sal nie deel aan die koninkryk van Christus en van God hê nie (Ef 5:5).

Hoehner (2004; vgl. ook Fowl 2012:125-214) toon aan dat die woord oun [dus, daarom] en die woord peripateo [wandel] as struktuurmerkers in Efesiërs 4-6 dien. Hierdie twee woorde kom telkens saam voor om 'n nuwe deel van sy argument aan te dui (Jordaan 1990:65, 66). Op grond van hierdie struktuurmerkers toon Hoehner (2004:vii, 62, 66-69) die volgende fasette van die kerk se lewe in hierdie wêreld volgens Efesiërs 4-6 aan (vgl. ook Breed 2013b).

The conduct of the church $(4: 1-6: 24)$ :
A. Walk in unity $(4: 1-16)$
B. Walk in holiness (4:17-32)
C. Walk in love (5:1-6)
D. Walk in light (5:7-14)
E. Walk in wisdom (5:15-6:9)
F. Stand in warfare (6:10-20)
G. Conclusion (6:21-24).

Elkeen van hierdie fasette sou ontleed kon word om die rol van die verlossingsdade van God aan te toon met betrekking tot die sendingopdrag van die kerk. Vanweë die beperkte omvang van hierdie artikel word slegs op Efesiërs 6:10-20 (F) gefokus.

\section{Die verlossing deur God soos dit na vore kom in sy wapenrusting}

Hoehner (2004:500) toon aan dat die gereelde struktuurmerker (peripateo) saam met oun hier vervang word met histemi [staan] en dat dié vers met die woord loipon [eindelik, ten slotte] ingelei word. Stott (1999:260-262) beskryf die lyn van Paulus se argumentasie deur die hele brief en sê dat Efesiërs 6:10 die inleiding is van ' $n$ waarskuwing aan die gelowiges dat die teenstand van die bose magte ' $n$ harde werklikheid is. Satan en sy magte wil God se plan in die wiele ry en die kerk vernietig. Paulus begelei die gelowiges in die gevegskuns om hierdie vyand te verslaan. Cohick $(2010: 152,153)$ toon aan dat die kerntemas wat in die brief hanteer word in Efesiërs 6:10-20 weer ter sprake gebring word. Loipon lei 'n perikoop in wat as konklusie van die hele brief gesien kan word. ${ }^{9}$ Paulus stuur sy lesers weg met die opdrag, na alles wat hy in die brief gesê het, om vas te staan in dit wat hulle ontvang het, sodat Satan en sy magte nie in hulle doel sal slaag nie:

Die eerste opdrag in hierdie toerusting vir die oorlog is dat hulle kragtig (endunamoo) in die Here en in die krag (kratos) van sy sterkte (isgus) moet word. Hierdie opdrag eggo Efesiërs 1:19 wanneer Paulus bid dat die gemeente sal begryp 'wat die uitnemende grootheid van sy [God se] krag (dinamus) is vir ons wat glo, na die werking van die krag (kratos) van sy sterkte (isgus)' (1953-vertaling). Ook in Efesiërs 3:16 bid Paulus 'dat Hy aan julle mag gee (krataioo) na die rykdom van sy heerlikheid om met krag (dinamus) versterk te word deur sy Gees in die innerlike mens'.

Hierdie versterking deur die Gees moet daartoe lei dat Christus in hulle sal woon en hulle die omvang van sy liefde sal begryp en met die volheid van God vervul sal wees (Ef 3:17-19). Hierna (Ef 3:20-21) sê Paulus dat God in die kerk geloof moet word. Hy beskryf God in hierdie verse soos volg:

En aan Hom wat mag het (dunamai)om te doen ver bo alles wat ons bid of dink, volgens die krag (dunamis) wat in ons werk, aan Hom die heerlikheid in die gemeente in Christus Jesus deur alle geslagte tot in ewigheid! Amen.

In al drie hierdie gedeeltes word verskillende woorde vir krag en bekragtiging gebruik en in al drie gedeeltes is

9. Sommige navorsers sien Efesiërs 6:10-20 slegs as ' $n$ samevatting van Efesiërs 4-6 (Hoehner 2004:817). Ander navorsers beskou dit egter as ' $n$ samevatting van die hele brief (Arnold 1989:103, 105; Fee 1994:723). 
daar sprake van konfrontasie met die vyandelike magte (vgl. Ef 1:20, 21; 3:10-13; 6:10-12); in al drie gedeeltes gaan dit oor die gelowiges wat van die drie-enige God krag ontvang vanuit hulle kennis van Hom, om hulle roeping volgens sy raadsplan uit te voer (Petrenko 2011:185, 186).

Die opdrag 'word kragtig in die Here' (Ef 6:10) begelei die gelowiges om in hulle stryd krag te put vanuit 'n noue persoonlike eenheid (wat voortvloei uit 'n groeiende ervaringskennis) met die drie-enige God. Wanneer hy byvoeg 'en in die krag van sy sterkte', moet hierdie opdrag in die lig van Paulus se twee gebede (Ef 1:15-23; Ef 3:14-21) begryp word. In hulle stryd kan hulle in geloof, biddend verwag dat God deur sy Gees in en deur hulle sal werk met dieselfde krag waarmee Hy Jesus uit die dood opgewek het en waarmee Hy dinge doen wat ver bo dit is wat die mens kan bid of dink. In hierdie bekragtiging speel die begrip van dit wat hulle kan verwag wanneer hulle hulle roeping uitleef (die hoop van hulle roeping; Ef 1:18) en die omvang van Christus se liefde $(E f 3: 18,19)$ 'n belangrike rol (vgl. Hoehner 2004:821, 822). Hierdie bekragtiging kan plaasvind omdat hulle in Christus is en Christus in hulle is (Ef 3:17; vgl. Joh 15; Fowl 2012:202, 203; Reinhard 2005:521, 529-531).

God se plan met die skepping, met elke gelowige en die kerk bring twee koninkryke onvermydelik in botsing (Kol 1:13). God se plan is om die heerskappy van Christus oor die ganse skepping in volle vervulling te bring (Ef 1:22, 23). Hierteen is die bose magte in opstand. Die kerk en elke gelowige se optrede tydens hierdie botsing word in Efesiërs 6:10-20 uitgespel. Hulle moet in hierdie stryd (Ef 6:11) vasstaan, want niemand wat goddeloos lewe, sal deel hê aan die koninkryk van Christus en van God nie (Ef 5:5).

God stel hulle in staat om in hierdie worstelstryd te kan vasstaan. Hierdie stryd gaan oor die harte en gedagtes van die gelowiges (Ef 4:20-24), want dit is 'n stryd teen die listige aanslae van Satan (Ef 6:11). In hierdie stryd kan die gelowiges en die kerk as eenheid slegs vasstaan indien hulle hulself voortdurend met die wapenrusting bewapen wat God verskaf. Wanneer die wapenrusting van nader bestudeer word, is dit duidelik dat hierdie wapens die verlossingsdade van die drie-enige God is.

\section{Die verlossing deur God soos dit na vore kom in die waarheid as deel van die wapenrusting}

'n Bespreking van die eerste deel van die wapenrusting dui aan dat dit 'n gawe van God is wat aktief deur die gelowiges gebruik moet word in die geveg teen Satan.

Die gordel is die waarheid. Wat Paulus met die waarheid bedoel, kan uit Efesiërs 4:21 afgelei word waar hy sê dat die waarheid in Jesus Christus is (vgl. 'Die leer oor die Drie-eenheid as skuilplek vir dwaalleer' hierbo). Jesus self het gesê dat Hy die weg en die waarheid en die lewe is (Joh 14:6) en dat diegene wat sy woorde bewaar, die waarheid sal ken en dat die waarheid hulle sal vry maak (Joh 8:31, 32; Breed 2013c:232). Hierdie waarheid staan teenoor die leuens van Satan waarmee hy die mens wil vermoor (Joh 8:44; vgl.
Breed 2013c:234). In Efesiërs 4:15 word die groei van die gelowiges om meer en meer soos Christus te word, afhanklik daarvan gemaak dat hulle in liefde by die waarheid sal bly. Dit sal verseker dat hulle standvastig sal wees en nie deur allerlei listige, bedrieglike planne van mense verlei sal word nie (Ef 4:14). In Efesiërs 5:6-9 word die gelowiges gewaarsku om hulle nie te laat mislei nie; die werke van die duisternis word teenoor die werke van die lig gestel. Die gelowiges is kinders van die lig, want 'die vrug van die Gees bestaan in alle goedheid en geregtigheid en waarheid' (Ef 5:9). Omdat die kinders van die lig die Gees van God het, kan hulle die wil van God onderskei en die werke van die duisternis bestraf. Omdat hulle die waarheid deur die Gees ken, kan hulle in die lig lewe en die duisternis oorwin (Petrenko 2011:203). Die gordel as deel van die wapenrusting is dus die waarheid wat in Christus geopenbaar is en die gelowiges in hulle diepste wese verander; hierdie waarheid kan die gelowiges prakties in elke situasie van die lewe onder leiding van die Gees van God toepas (Petrenko 2011:204; Reinhard 2005:524).

Op dieselfde wyse sou elke deel van die wapenrusting bespreek kan word om aan te toon dat dit 'n gawe van God is waardeur Hy sy verlossingsplan ten uitvoer bring. Die gelowiges moet hierdie wapens gebruik om in die stryd van elke dag vas te staan (vgl. Reinhard 2005; Wenkel 2007).

Die koninkryk van God kan nie bloot in die algemeen beskryf word in die betekenis van 'om deel te kry aan die shalom ${ }^{10}$ van God' nie. Die koninkryk van God breek in mense se lewe deur wanneer hulle deur die Gees nuutgemaak word (uit die dood opgewek word), die geloof as genadegawe ontvang en vanuit die verlossing begin lewe. Die Heilige Gees is voortdurend besig om die verlossingswerk van Christus in die gelowiges se lewe ' $n$ werklikheid te maak (Breed 2013a). Om hierdie rede kom die opdrag aan die gelowiges 'laat julle vervul met die Gees' (Ef 5:18). Waar die koninkryk deurbreek, is daar nie net shalom nie, maar ook 'n geveg tot die dood toe. Gelowiges het deur die Gees nou slegs 'n voorsmaak - 'n deposito (Rom $8: 23$ ) - en 'n waarborg van die volle shalom wat kom. Hierdie voorsmaak en lewende hoop (verwagting) van die volle shalom gee hulle krag om in die stryd te volhard.

Die sendingtaak van die kerk kan nie uitgevoer word wanneer terme soos missio Dei vaag en veralgemenend gebruik word nie. God se waarheid moet verkondig word en daarom moet sy verlossingsdade helder en duidelik teenoor die leuens van Satan uitgespel word. Akkommodasie van leerstellings wat staan teenoor die waarheid wat in Christus is, kom neer op deelname aan die werke van die duisternis. Sending is ook ' $n$ konfrontasie van die duisternis met die lig; dit berus op wysheid wat die wil van God in elke situasie onderskei. Die kerk groei alleen wanneer die waarheid in liefde verkondig word.

Hierdie opsomming kan nie naastenby reg laat geskied aan die rykdom van die leer oor die goddelike Drie-eenheid as die ruggraat van alle uitreike na die wêreld nie ${ }^{11}$ - selfs in 10.Vergelyk Buys (2013:76-78) vir'n bespreking van die bybelse begrip van shalom. 11.Vir' $n$ vollediger bespreking, vergelyk Hastings (2012:80-118) en Wright (2008; 2010). 
die Efesiërbrief is daar veel meer wat ontgin kan word. Dit val egter nie binne die skopus van hierdie artikel om dit te probeer doen nie. Die opsomming is egter genoegsaam om aan te toon dat die uitreik na die wêreld (sending) nie slegs begrond kan word in die blote feit dat die Seun en die Gees en die kerk gestuur is nie. Sending moet in die ewige raadsplan van God en in die volle rykdom van dit wat in die Woord aan ons oor die Drie-eenheid geopenbaar is, begrond word. Selfs dan moet elke navorser, net soos Paulus (Fil 3:7-14), diep onder die indruk van die voorlopigheid van hulle kennis wees.

\section{Konklusie}

Hierdie artikel het aangetoon dat die klem wat wêreldwyd op missio Dei geplaas word, 'n belangrike ontwikkeling is wat die kerk nader daaraan kan bring om haar roeping in hierdie wêreld uit te leef. Daar is egter ook aangetoon dat die ongekwalifiseerde gebruik van die term missio Dei en ander verwante begrippe tot benaderings van die kerk se sendingtaak lei wat nie met die leer van die Bybel ooreenstem nie. In die derde plek is kortliks uit die Efesiërbrief aangetoon hoe die missio Dei-begrip se betekenisinhoud vanuit die Bybel gevul kan word. Hieruit is aangetoon dat:

- die begrip missio Dei nie op so 'n wyse gebruik behoort te word asof dit die volle wese van God beskryf nie;

- die begrip missio Dei die ewige raadsplan van God behoort te beskryf wat deur die unieke en gesamentlike werk van die drie Persone in die goddelike Drie-eenheid, in die volheid van die tyd, onkeerbaar tot uitvoer gebring word;

- sending (missio) voortvloei uit die wese van God, maar nie die wese van God omvat nie - missio Dei beskryf God se dade wat uit sy genade en opsoekende liefde voortvloei;

- sending op die geopenbaarde waarheid van God berus, waardeur dié wat glo weer gebore (herskep) word om as oorwinnaar oor die sonde 'n nuwe lewe in navolging van God te leef;

- die verlossingsdade van die drie-enige God 'n kardinale rol behoort te speel in die begronding van die sendingtaak in die leer oor die Drie-eenheid;

- sending (missio) as koninkrykswerk stryd en konfrontasie met die bose magte sal bring en dat die oorwinning behaal word deurdat die kerk God se verlossingsdade volhardend in die praktyk, konkreet op hulle eie en ander mense se lewens toepas.

Die begrip missio Dei behoort vanuit die perspektief van die Efesiërbrief met die volgende betekenisinhoud gebruik te word: Missio Dei dui op elke optrede van die drie-enige God om sy ewige raadsplan (ekonomia) tot uitvoer te bring.

Elkeen van die Persone in die Drie-eenheid het in die uitvoering van hierdie plan 'n unieke rol. God is dus die begin en die einde van die sending en sending vloei nie in die eerste plek voort uit die inisiatief van die kerk nie. God se plan behels dat Hy die harmonie wat deur die sondeval versteur is, gaan herstel deur alles weer onder Christus bymekaar te bring. Die kerk as liggaam van Christus beklee binne hierdie plan 'n essensiële rol as die draer van die waarheid. In die uitvoering van hierdie plan word God nie sy dade nie; Hy is ook nie tot sy ekonomie beperk nie. God openbaar wel iets van sy wese in sy ekonomie en daarom kan ons weet dat sending uit die wese van God voortvloei. God openbaar sy wese in sy dade. Uit hierdie dade van God kan iets van sy wese ontdek word, terwyl erkenning daaraan gegee moet word dat geen mens God ten volle kan ken nie.

\section{Erkenning Mededingende belange}

Die outeur verklaar dat hy geen finansiële of persoonlike verbintenis het met enige party wat hom nadelig kon beïnvloed het in die skryf van hierdie artikel nie.

\section{Literatuurverwysings}

Arnold, C.E., 1989, Ephesians: Power and magic - The concept of power in Ephesians in light of its historical setting, Cambridge University Press, Cambridge.

Bauckham, R., 2008, Jesus and the God of Israel, Paternoster, Milton Keynes.

Bolt, J. \& Muller, R.A., 1996, 'Does the church today need a new "mission paradigm"?', Calvin Theological Journal 31, 196-208.

Bosch, D.J., 1985, 'Missions in biblical perspective: A review essay', Internationa Review of Mission 74, 533-534.

Bosch, D.J., 2009, Transforming mission: Paradigm shifts in theology of mission, Orbis, Maryknoll.

Braaten, C.E., 1990, 'The Triune God: The source and model of Christian unity and mission', Missiology: An International Review 18(4), 415-427. http://dx.doi. org/10.1177/009182969001800402

Breed, G., 2012, 'Nuut gedink oor die wese en inhoud van die dienswerk van die diaken', HTS Teologiese Studies/Theological Studies 68(1), Art. \#1059, 8 pages.

Breed, G., 2013a, 'Metateoretiese vertrekpunte ten opsigte van wetenskaplike navorsing in gemeentebediening', In die Skriflig/In Luce Verbi 47(1), 1-10.

Breed, G., 2013b, 'Ministry of the congregation according to the letter to the Ephesians', Acta Theologica, (in pers).

Breed, G., 2013c, 'Metateoretiese vertrekpunte ten opsigte van wetenskaplike navorsing in die Pastorale Wetenskap', in B.J. de Klerk \& F.W. de Wet (reds), Met die oog op God: Voorveronderstellings van die reformatoriese invalshoek op Praktiese Teologie, bl. 225-250, V\&R, Pretoria.

Buys, P.J., 2011, 'God's mission and missional churches', voordrag by TSP, Potchefstroom.

Buys, P.J., 2013, 'A missional response to poverty and social injustice', in S.T. Logan (ed.), Reformed means missional following Jesus into the world, pp. 67-96, New Growth Reformed Greensboro.

Cohick, L.H., 2010, Ephesians: A new covenant commentary, Cascade Books, Eugene.

De Beer, C., 2012, 'The characteristics of a missional church as part of the missio Dei', MTh dissertation, Faculty of Theology, NWU, Potchefstroom.

Driscoll, M., 2008, 'Navigating the Emerging Church highway', Christian Research Journal 31(4), 1-20.

Engelsviken, T., 2003, 'Missio dei: The understanding and misunderstanding of a theological concept in European churches and missiology', International Review of Mission 92(4), 481-497. http://dx.doi.org/10.1111/j.1758-6631.2003.tb00424.x

Fee, G.D., 1994, God's empowering presence: The Holy Spirit in the letters of Paul, Hendrickson, Peabody.

Flett, J.G., 2010, The witness of God: The Trinity, missio Dei, Karl Barth, and the nature of Christian community, Grand Rapids, Eerdmans.

Floor, L., 2011, 'Een blauwdruk voor de toekomst, Efeziërs 1:9-10', In die Skriflig 45(2 \& 3), 467-480.

Fowl, S.E., 2012, Ephesians, a commentary, John Knox Press, Louisville.

Goheen, M.W., 2011, A light to the nations: The missional church and the biblical story, Baker Academic, Grand Rapids.

Günter, W., 1998, 'Gott selbst treibt Mission: Das Moddell der "Missio Dei"' in K. Schäfer (Hrsg.), Plädoyer für Mission: Beiträge zum Verständnis von Mission heute, p. 56, Evangelische Missionwerk in Deutschland, Hamburg.

Haaipiainen, T., 2012, 'The development and outlines of missio Dei in G.F. Vicedom's theology', Swedish Missiological Themes 100(1), 45-64.

Hastings, R., 2012, Missional God, missional church: Hope for re-evangelizing the West, InterVarsity, Downers Grove.

Hirsch, A., 2006, The forgotten ways: Reactivating the missional church, Brazos Press, Grand Rapids.

Hoehner, H.W., 2002, Ephesians, an exegetical commentary, Baker Academic, Michigan. 
Hoehner, H.W., 2004, Ephesians, an exegetical commentary, Baker Academic, Michigan.

Hoffmeyer, J.F., 2001, 'The missional Trinity', Dialog 40(2), 108-111. http://dx.doi. org/10.1111/0012-2033.00063

James, F.A., 2013, 'Afterword: Missional is mission critical', in S.T. Logan (ed.), Reformed means missional following Jesus into the world, pp. 377-378, New Growth Press, Greensboro.

Janse van Rensburg, J., 2011, Jesus is die Een: Verloor ons nie die evangelie in die Emerging Church nie?, Christelike Media Publikasies, s.I.

Jordaan, C.J.G., 1990, ‘Die verhouding tussen indikatief en paraklese in die brief aan die Efesiërs', In die Skriflig 24(1), 49-69. http://dx.doi.org/10.4102/ids.v24i1.1341

Keller, T., 2012, Center Church: Doing balanced, gospel-centered ministry in your city Zondervan, Grand Rapids.

Matthey, J., 2002a, 'Mission als anstoßiges Wesensmerkmal der Kirche', Zeitschrift für Mission 28(3), 221-239.

Matthey, J., 2002b, 'God's mission today: Summary and conclusions', International Review of Mission 92(4), 579-586.

Meeks, M.D., 2006, 'The social Trinity and property', in M. Volf \& M. Welker (eds.) God's life in Trinity, pp. 13-21, Fortress, Minneapolis.

Müller, K., 1985, Missionstheologie, Reimer, Berlin.

Muse, T.G., 2011, Shift or drift: A critique of the 'Missional manifesto', viewed 01 March 2014, from http://theaquilareport.com/ shift-or-drift-a-critique-of-themissional-manifesto/

Niemandt, C.J.P., 2008, "n Stormkompas in tye van aanpasbare verandering kontoere van missionêre leierskap', Verbum et Ecclesia 29(3), 606-635.

Niemandt, N., 2007, Nuwe drome vir nuwe werklikhede, Lux Verbi, Wellington. http://dx.doi.org/10.4102/ve.v29i3.38

Petrenko, E., 2011, Created in Christ for good works, the integration of soteriology and ethics in Ephesians, Pater Noster, Milton Keynes.

Pretorius, M., 2006, 'The theological centre of Pauline theology as it relates to the Holy Spirit', Hervormde Teologiese Studies 62(1), 253-262. http://dx.doi org/10.4102/hts.v62i1.354

Purves, J., 2011, 'The missional doxology of the Philippian hymn', Baptistic Theologies $3(1), 15-30$

Rahner, K., 1970, The Trinity, Herder, New York.

Reinhard, D.R., 2005, 'Ephesians 6:10-18: A call to personal piety or another way of describing union with Christ?', Journal of the Evangelical Theological Society $48(3), 521-532$.
Richebächer, W., 2003, 'Editorial', International Review of Mission 92(4), 463-467.

Roxburgh, A.J. \& Boren, M.S., 2009, Introducing the missional church, what it is, why it matters, and how to become one, Baker, Grand Rapids.

Scott, E.L., 2010, 'A theological critique of the emerging, postmodern missiona church/movement', Evangelical Review of Theology 34(4), 335-346.

Smit, G.H., 2010, 'Aanbidding en prediking in missionale gemeentes - homiletiesliturgiese beskouinge van missionêre gemeentebediening', HTS Teologiese Studies/Theological Studies 66(1), 1-6. http://dx.doi.org/10.4102/hts.v66i1.313

Stott, R.W., 1999, The message of Ephesians: God's new society, InterVarsity, Leicester.

Sundermeier, T., 2003, 'Missio Dei today: On the identity of Christian mission', International Review of Mission 92(4), 560-578. http://dx.doi. org/10.1111/j.1758-6631.2003.tb00429.x

Sweet, L., 2010, The church of the perfect storm, Abingdon, Nashville.

Van Gelder, C., 2007, 'How missiology can help inform the conversation about the missional church in context', in C. van Gelder (ed.), The missional church in context: Helping congregations develop contextual ministry, pp. 12-43, Eerdmans, Grand Rapids.

Van Gelder, C. \& Zscheile, D.J., 2011, The missional church in perspective, mapping trends and shaping the conversation, Baker Academy, Grand Rapids.

Vetö, M., 1996, 'Spiritual knowledge according to Jonathan Edwards', Calvin Theological Journal 31, 161-181.

Vicedom, G.F., 1958, Missio Dei, Chr. Kaiser Verlag, Munich.

Volf, M., 2006a, 'Being as God is, Trinity and generosity', in M. Volf \& M. Welker (eds.) God's life in Trinity, pp. 3-12, Fortress, Minneapolis.

Volf, M., 2006b, "'The Trinity is our social programme": The doctrine of the trinity and the shape of social engagement', in A.J. Torrance \& M. Banner (eds.), The doctrine of God in theological ethics, pp. 105-124, Clark, New York.

Wenkel, D.H., 2007, The 'breastplate of righteousness' in Ephesians 6:14 imputation or virtue?, Tyndale Bulletin 58(2), 275-287.

Witherington B. III, 2011, Paul's letter to the Philippians: A socio-rhetorical commentary, Eerdmans, Grand Rapids.

Wright, C.J.H., 2008, The mission of God, InterVarsity, Nottingham.

Wright, C.J.H., 2010, The mission of God's people, Zondervan, Grand Rapids.

Wright, C.J.H., 2013, 'Foreword: What do we mean by “missional”?', in S.T. Logan (ed.), Reformed means missional following Jesus into the world, pp. xi-xv, New Growth Press, Greensboro.

Wright, N.T., 2006, Evil and the justice of God, InterVarsity, Downers Grove. 